\title{
Ghrelin as an Anti-Sepsis Peptide: Review
}

\author{
Nimisha Mathur ${ }^{1}$, Syed F. Mehdi ${ }^{1}$, Manasa Anipindi ${ }^{1}$, Monowar Aziz ${ }^{1,2}$, \\ Sawleha A. Khan ${ }^{1}$, Hema Kondakindi ${ }^{1}$, Barbara Lowell ${ }^{1}$, Ping Wang ${ }^{1,2}$ and Jesse Roth ${ }^{1 *}$ \\ ${ }^{1}$ Laboratory of Diabetes, Obesity, and Other Metabolic Disorders, The Feinstein Institutes for Medical Research, Manhasset, \\ NY, United States, 2 Center for Immunology and Inflammation, The Feinstein Institutes for Medical Research, Manhasset, NY, \\ United States
}

Sepsis continues to produce widespread inflammation, illness, and death, prompting intensive research aimed at uncovering causes and therapies. In this article, we focus on ghrelin, an endogenous peptide with promise as a potent anti-inflammatory agent. Ghrelin was discovered, tracked, and isolated from stomach cells based on its ability to stimulate release of growth hormone. It also stimulates appetite and is shown to be anti-

OPEN ACCESS

Edited by:

Teun J. De Vries,

VU University Amsterdam,

Netherlands

Reviewed by:

Patric Delhanty,

Erasmus MC, Netherlands

Sergio Iván Valdés-Ferrer,

Instituto Nacional de Ciencias Médicas y Nutrición Salvador Zubirán (INCMNSZ), Mexico

${ }^{*}$ Correspondence: Jesse Roth

JRoth2@northwell.edu

Specialty section: This article was submitted to Inflammation,

a section of the journal

Frontiers in Immunology

Received: 25 September 2020 Accepted: 09 December 2020

Published: 28 January 2021

Citation:

Mathur N, Mehdi SF, Anipindi M, Aziz M, Khan SA, Kondakindi H, Lowell B, Wang P and Roth J (2021)

Ghrelin as an Anti-Sepsis Peptide: Review.

Front. Immunol. 11:610363. doi: 10.3389/fimmu.2020.610363 inflammatory in a wide range of tissues. The anti-inflammatory effects mediated by ghrelin are a result of both the stimulation of anti-inflammatory processes and an inhibition of pro-inflammatory forces. Anti-inflammatory processes are promoted in a broad range of tissues including the hypothalamus and vagus nerve as well as in a broad range of immune cells. Aged rodents have reduced levels of growth hormone $(\mathrm{GH})$ and diminished immune responses; ghrelin administration boosts $\mathrm{GH}$ levels and immune response. The anti-inflammatory functions of ghrelin, well displayed in preclinical animal models of sepsis, are just being charted in patients, with expectations that ghrelin and growth hormone might improve outcomes in patients with sepsis.

Keywords: ghrelin, growth hormone, sepsis, cytokine storm, inflammation, anti-inflammation

\section{INTRODUCTION}

Sepsis is a life-threatening organ dysfunction caused by a dysregulated host response to infection (1) which continues to be a leading cause of death in the United States. According to the Center for Disease Control, each year, at least 1.7 million adults develop sepsis in America and nearly 270,000 Americans die as a result of it. Sepsis causes an exaggerated production of pro-inflammatory cytokines by the activated immune-reactive cells that result in multiple organ failure leading to death (2). Despite the growing understanding of the pathophysiology of sepsis, progress has been slow in the therapeutic control of sepsis (3).

According to recent studies, peptide hormones of mammals like ghrelin, hCG, glucagon, glucagonlike peptide 1 , and vasopressin have shown promising effects on sepsis, presumably based on their antiinflammatory properties. In this review article, we focused on ghrelin and its mechanism of action on various organs in sepsis. Although the beneficial role of ghrelin in downregulating the expression of proinflammatory cytokines was reported in several studies $(4,5)$ the mechanism of action of ghrelin in sepsis has only been clarified within the last few years. Ghrelin was discovered to downregulate the expression of pro-inflammatory cytokines such as tumor necrosis factor $\alpha$ (TNF- $\alpha$ ), interleukin (IL)-6, and IL-1 $\beta$ (4), 
while upregulating the expression of anti-inflammatory cytokines e.g., IL-10 and transforming growth factor (TGF) $\beta$ (6).

Ghrelin, a peptide hormone, is widely recognized as a growth hormone secretagogue (7) and independently acts as an appetite stimulant. Besides these classic well-established roles of ghrelin, it has been shown to affect many organ systems including the central nervous system as well the cardiovascular, gastrointestinal, reproductive, and immune systems (Tables 1 and 2). Even after 20 years of its discovery, the role of ghrelin in regulating inflammation has not been well defined (7, 29-31) (Figure 1). In this review, we focus on the role of ghrelin in inflammation and its emerging usefulness in the treatment of sepsis.

TABLE 1 | Physiology and biochemistry of ghrelin: (8-10).

\begin{tabular}{|c|c|}
\hline Gene & Chromosome 3 (3q26.2) \\
\hline Synthesis & Stomach ghrelin cells \\
\hline Precursor & $\begin{array}{l}\text { Preproghrelin, } 117 \text { amino acid peptides } \rightarrow \text { post-translational } \\
\text { cleavage } \rightarrow \text { Proghrelin }\end{array}$ \\
\hline Hormone & Ghrelin, 28 amino acid peptides \\
\hline Receptor & $\begin{array}{l}\text { GHSR (Growth hormone secretagogue receptor), G-protein } \\
\text { coupled receptor }\end{array}$ \\
\hline $\begin{array}{l}\text { Main } \\
\text { physiological } \\
\text { role }\end{array}$ & $\begin{array}{l}\text { 1. Growth hormone release; Starvation, same as in calorie } \\
\text { restriction in sepsis, causes to synthesize octonylated peptide } \\
\text { ghrelin from proghrelin by Ghrelin O- acyltransferase (GOAT) } \\
\text { which stimulates Growth hormone from pituitary cells to } \\
\text { normalize blood glucose levels (10). Sepsis and prolonged } \\
\text { illness can cause hyperglycemia. Given the impact of Ghrelin in } \\
\text { controlling glucose homeostasis, the beneficial outcomes of } \\
\text { Ghrelin treatment in sepsis could be mediated through } \\
\text { maintaining normoglycemia in septic patients. } \\
\text { 2. Appetite stimulation; } \\
\text { 3. Anti-inflammation }\end{array}$ \\
\hline
\end{tabular}

\section{GHRELIN SYNTHESIS}

The in vivo growth hormone-releasing properties of ghrelin energized the path to its discovery, purification, and early naming but later recognition of a much richer menu of activities have subordinated the link to growth. Starting with rat stomach, Kojima et al. purified an endogenous ligand that activates GHSR-1A (growth hormone secretagogue receptor type 1A), a 28-amino acid peptide produced by the post-translational cleavage of preproghrelin (117 amino acids) $(2,3)$ After that cleavage, proghrelin is acylated by ghrelin $\mathrm{O}$ - acyltransferase (GOAT) at the third serine residue to produce the active hormone, acylated ghrelin (41-43). Ghrelin is released from the cells in the stomach that have compact electron dense granules. Most of these cells are in oxyn4tic mucosa of the fundus. Small numbers of cells are resident in pyloric glands of the stomach and the small intestine $(7,44-46)$. Most of the circulating ghrelin originates from cells of the gastrointestinal tract as well as the pancreas $(46,47)$.

\section{GHRELIN RECEPTORS ARE INVOLVED IN ANTI-INFLAMMATORY ACTIVITIES OF GHRELIN}

The active ghrelin receptor, known widely as GHS-R1a, is a Gprotein coupled receptor (GPR) (48) with seven transmembrane domains. GHS-R1a belongs to the sub-family of class A Gprotein- coupled receptors that includes the motilin receptor, neurotensin-1 and -2 receptors and neuromedin -1 and -2

TABLE 2 | Anti-inflammatory role of ghrelin in animal and human studies.

Alzheimer's disease

(male Tg APPSwDI mice (11),

male ICR mice (12)

Multiple sclerosis (Sprague Dawley rats) (14)

Subarachnoid hemorrhage

(Male Wistar albino rats)

Acute lung injury in a traumatic brain injury

(TBI mice model)

Intestinal injury due to traumatic brain injury, (Balb/c mice model)

Chronic respiratory

Diseases

(human study)

Atherosclerosis

(mice model, lipid rich diet fed)

Gastric Ischemia reperfusion injury (Male

Wistar rats $(24,25)$, Male Sprague Dawley

rats (26)

Inflammatory bowel disease, Models

-Sprague-Dawley rats of both sexes (19),

Balb/c mice (6-8 weeks old) (27)

Obesity (C57BL/6 mice model)
Treatment with ghrelin reduced inflammation of the microglia. It also decreased tau phosphorylation via the PI3-K/Akt-

GSK pathway in hippocampal neuron cultures. Ghrelin also decreased levels of amyloid-beta peptide (11-13).

It decreases inflammatory brain infiltration, inhibits NF-kB, suppresses microglial aggregation around vessels in the rats $(13,14)$. Ghrelin also showed a growth promoting effect on neuronal cells by inducing modifications in the growth hormone secretagogue receptor type 1 (GHS-R1) expression (15).

Ghrelin reduced the proinflammatory mediators, prevented the reduction of endogenous antioxidants and preserved the endothelial integrity of cerebral arteries (16).

-Ghrelin reduced the activation of NF-kB, pro-inflammatory factors including IL-1 $\beta$, IL-6, TNF- $\alpha$, and IL-18, and the apoptosis related proteins like NLRP3, Caspase1-P20, and HMGB1 in the lung tissues (17)

- It also reduced the peripheral macrophage invasion and reduced lung vascular permeability thereby improving lung function (17)

Decreases intestinal permeability and TNF- $\alpha$ levels (18).

-Ghrelin suppressed the airway inflammation by decreasing neutrophil accumulation, suppressing levels of IL-8 and TNF- $\alpha$ (19) (Figure 2)

Ghrelin has also been shown to increase appetite and body weight in cachectic patients.

Ghrelin receptor agonists increased the cholesterol removal from macrophages and reduced the plaque formation in mice maintained on a high fat diet (20). Has an anti-inflammatory action in the regulation of atherosclerosis (20-23).

1. Ghrelin reduced induction of cytokines, neutrophil infiltration, and production of reactive oxygen species (24).

2. The protective effect of ghrelin on gastric mucosa in mice is dependent on increased gastric blood flow, endogenous nitric oxide release, prostaglandin release, decreased TNF- $\alpha$ expression in inflammatory cells, and intact sensory nerves $(25,26)$.

Ghrelin inhibits inflammation and protects the mucosa $(19,27)$

Ghrelin reduced mRNA expression of TNF- $\alpha$, TGF- $\beta$, IL-1 $\beta$, IL-6, and Collagen I (28) 


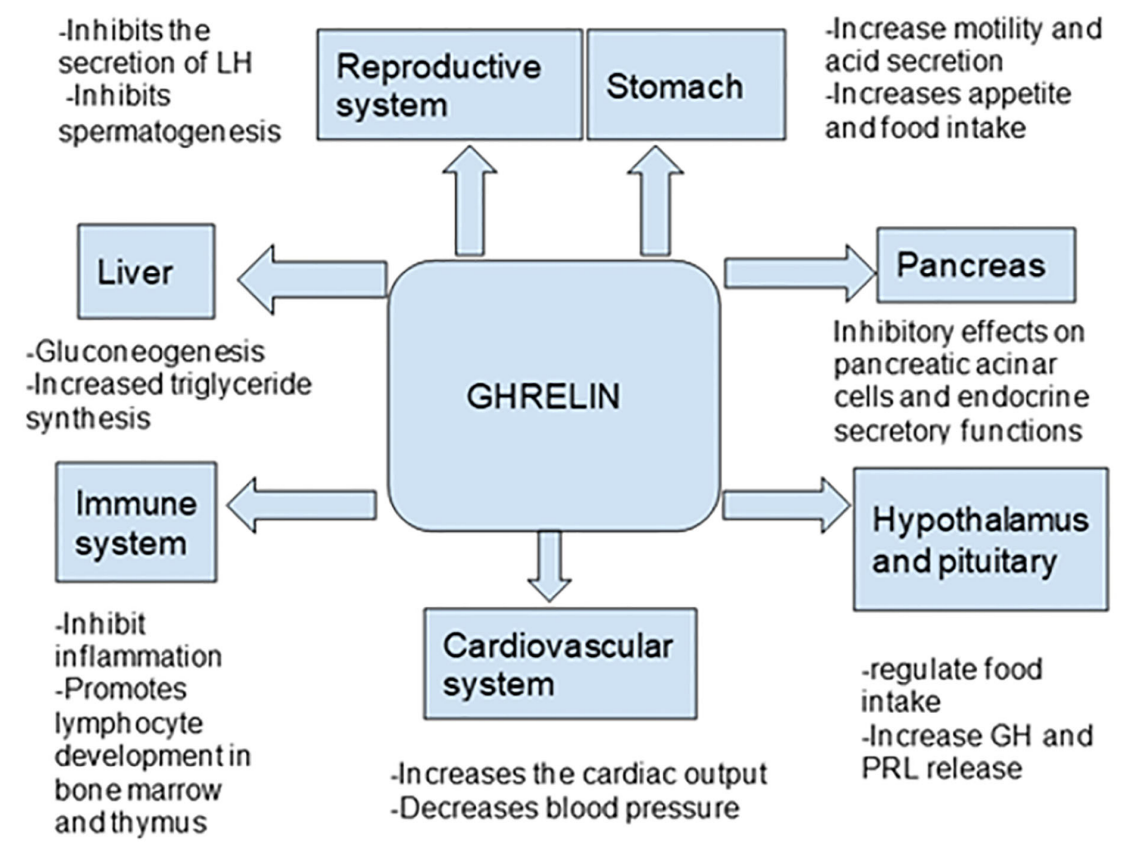

FIGURE 1 | Effects of ghrelin on different organ systems (31-40).

receptors (49). Growth hormone secretagogue receptor $1 \mathrm{~b}$, (GHS-R1b) is also referred to as a receptor but is involved in modulating the 1a receptor (7) to growth hormone secretagogue, a synthetic peptide agent or small molecule compound that releases growth hormone from the pituitary (50-52).

As ghrelin has a short half-life, owing to its de-acylation by esterase in the circulation, its synthetic analog, growth hormonereleasing peptide-2 (GHRP-2) was used to study GHS-R(growth hormone secretagogue receptor) mediated effects. Anti-inflammatory effects of GHRP-2 occur by direct stimulation of immune cells, mediated by ghrelin receptors. GHRP-2 inhibited lipopolysaccharide-induced IL-6 release from peritoneal macrophages in vitro from arthritic rats. GHRP-2 also decreased production of ACTH and corticosterone, which are elevated in arthritic rats. It was also shown that human T- lymphocytes and monocytes expressed GHS- R, and ghrelin inhibits production of cytokines IL-1 $\beta$, IL- 6 , and TNF- $\alpha$ via GHS-R (49).

\section{DISTRIBUTION AND ACTION OF GHRELIN RECEPTORS}

The GHS-R-1a receptors are expressed in many organs including lung (especially alveolar macrophages), kidney, heart, intestine, liver, and adipose tissue $(2,3,29)$. Other prominent sites include the arcuate and ventromedial nuclei of the hypothalamus (53). They are also distributed on immune cells including monocytes, monocyte-derived dendritic cells, and T cells $(53,54)$. Typically, on activation of these immune cells, the G protein coupled GHSR1a receptor expression is significantly increased, leading to increased mobilization of calcium as well as cytoskeletal changes (55) (Figure 2). While the calcium mobilization via a G-protein coupled receptor is common, the extent of calcium release linked to ghrelin receptors is very prominent, analogous to the large amounts released by some of the very potent T-cell chemokine ligands (55), When T cells are activated, the ghrelin receptor expression is significantly increased which leads to increased influx of calcium. Also, ghrelin decreases the levels of IL- $1 \beta$ and IL- 6 from LPS treated monocytes. These effects are reversed when treated with ghrelin receptor antagonists (55). Overall, these findings suggest the important role of ghrelin and ghrelin receptors in inflammation.

\section{ANTI-INFLAMMATORY ACTIONS OF GHRELIN IN EXPERIMENTAL MOUSE MODELS}

The anti-inflammatory role of ghrelin has been established widely in diseases affecting many systems including the central nervous system, as well as immune, digestive, respiratory, skeletal, metabolic, and endocrine systems. Treatment with ghrelin decreases inflammation, thereby reducing the disease severity in multiple disorders including sepsis, inflammatory bowel disease, arthritis (57), pancreatitis, obesity (58-61), 


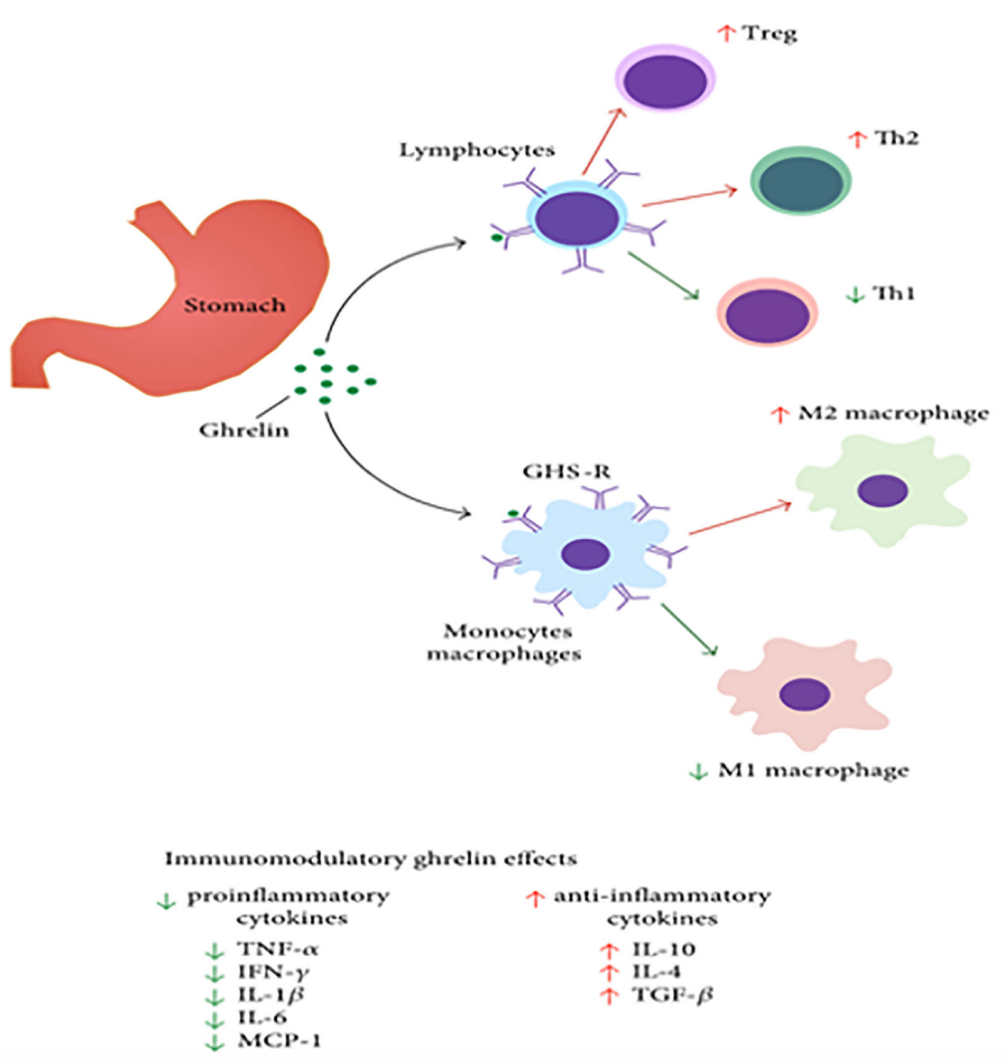

FIGURE 2 | Ghrelin's impact on immune cells, like macrophages, lymphocytes, and non-immune cells like epithelial or endothelial cells. [Modified from (55, 56)].

diabetic nephropathy (49, 62-65), cachexia, experimental autoimmune encephalomyelitis (66), and several mouse models of autoimmune chronic inflammatory states (13).

\section{IMMUNE SYSTEM}

One major role of ghrelin is to decrease inflammation from sepsis (67). The anti-inflammatory role of ghrelin has been studied in mouse models of sepsis. Post-treatment with a bolus intravenous injection of ghrelin into mice with sepsis significantly reduced the serum levels of TNF- $\alpha$ and IL-6 (4).

\section{NEUROPROTECTION}

Ghrelin promotes neuroprotective effects via its antiinflammatory properties. In rats, it reduces the brain damage induced by subarachnoid hemorrhage by decreasing the inflammation and preserving the endothelial integrity of cerebral arteries (16). Ghrelin receptor agonists also decrease beta-amyloid peptide and inflammation in the microglia of murine models of Alzheimer's disease $(11,12)$. It also delays and diminishes the symptoms in the experimental autoimmune encephalitis rat model of multiple sclerosis $(13,14)$.

\section{RESPIRATORY ILLNESSES}

In mice suffering from a chronic respiratory disease model, intravenous ghrelin decreases the airway inflammation (13). Similar benefits of ghrelin have also been observed in mouse models with acute lung damage associated with traumatic brain injury (17), and pancreatitis (68), as well as administration of bleomycin (69), oleic acid (70), and monocrotaline (71). In patients with asthma, ghrelin levels inversely correlated with disease severity (72).

\section{VASCULAR DISEASES}

In mouse models, ghrelin reduced inflammatory responses associated with ischemia-reperfusion injury including ulceration, tissue congestion, and neutrophil infiltration (24). It also was associated with a significant increase in gastric blood flow and reduction in gastric erosions $(25,26,73)$.

\section{DIGESTIVE SYSTEM}

Traumatic brain injury alone often results in dysfunction of multiple other organ systems. The intestines become inflamed 
with increased permeability and translocation of microbes. Ghrelin administration mitigates these alterations (18). In mice with colitis induced by trinitrobenzene sulfonic acid (TNBS), the production of chemo-attractants, chemokines, chemokine receptors and other pro-inflammatory mediators is tempered by ghrelin and IL-10, another anti-inflammatory cytokine (27). Ghrelin treatment is also associated with a remarkable increase in colonic blood flow compared to control animals.

In rats, when sensory nerves in the colonic mucosa are inactivated by capsaicin, the healing and vasodilatory properties of ghrelin are reduced, suggesting a role of sensory nerves in the healing promoted by ghrelin.

These experiments support the involvement of nitric oxide, prostaglandins, and sensory nerves in the protection of colonic mucosa by ghrelin. It is to be noted that in ulcerative colitis patients, the mRNA expression of ghrelin is significantly upregulated in inflamed colonic mucosa (74).

\section{METABOLIC DISEASES}

Des-acyl Ghrelin has been shown to prevent the development of pre-diabetes in a mouse model fed with a high fat diet, showing its potential therapeutic role in type 2 diabetes (75). It also reduced inflammation in mouse models of obesity (20-23, 28, 58-61, 76, 77).

\section{ANTI-FIBROTIC PROPERTIES}

Ghrelin has anti-inflammatory properties that are protective, reducing fibrosis in heart (myocardial infarction, chronic hypertension, doxorubicin induced cardiac fibrosis), lungs (idiopathic pulmonary fibrosis, diffuse fibrosing alveolitis, diffuse interstitial fibrosis), liver (viral infections, alcohol abuse, non-alcoholic fatty liver disease), kidneys (renal interstitial fibrosis), and skin (systemic sclerosis) (78).

\section{MECHANISMS INVOLVED IN THE PROTECTIVE ROLE OF GHRELIN IN INFLAMMATION}

\section{Inhibition of Pro-Inflammatory Cytokine Production}

Ghrelin inhibits the production of pro-inflammatory cytokines from monocytes, T-cells, and macrophages (55). It also inhibits leptin-induced pro-inflammatory cytokine expression including IL- $1 \beta$, IL-6, and TNF- $\alpha$ in human T lymphocytes and monocytes $(55,79)$.

\section{Ghrelin Inhibits HMGB1 (High Mobility Group Box 1) Protein}

HMGB1 is a nuclear protein encoded by the HMGB-1 gene. It is also transformed into a cytokine secreted by many immune cells including monocytes, macrophages, and dendritic cells (80). HMGB1 is also involved in stimulating the release of proinflammatory cytokines, including TNF- $\alpha$, IL-1, IL-6, and IL8 , thereby amplifying inflammation (81). In a mouse model, HMGB1 was released by cultured macrophages $8 \mathrm{~h}$ after stimulation with endotoxin, TNF- $\alpha$, or IL-1. Ghrelin treatment of macrophages inhibits the translocation of HMGB1 from nucleus to cytoplasmic compartment, thereby abrogating its secretion from activated (LPS-stimulated) macrophages. Ghrelin also reduces bacterial load in sepsis, which also indirectly contributes to less HMGB1 secretion $(55,82)$.

The delayed secretion of ghrelin by macrophages, stimulated by LPS, IL-1, and TNF- $\alpha$ may be part of a homeostatic checkpoint to prevent an all-out inflammatory response (83).

\section{Ghrelin Inhibits NF-kB and Other Genes Involved in Inflammation}

In sepsis, when the host immune system is activated by pathogen-associated molecular patterns (PAMPs) or damageassociated molecular patterns (DAMPs), a cascade of intracellular signal transduction pathways are stimulated, which lead to the activation of downstream transcription factor $\mathrm{NF}-\kappa \mathrm{B}$ and mitogen-activated protein kinase (MAPK). These activated signaling cascades enhance the expression of proinflammatory cytokines including IL- $1 \beta$, TNF- $\alpha$, IL-6, and IL12 (84). NF- $\kappa \mathrm{B}$ is involved in the pathogenesis of acute and chronic inflammatory diseases including sepsis. NF- $\kappa \mathrm{B} / \mathrm{Rel}$

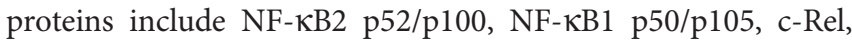
RelA/p65, and RelB. These proteins function as dimeric transcription factors that regulate the expression of genes relevant to a wide range of biological processes such as innate and adaptive immunity as well as inflammation. While inactive, $\mathrm{NF}-\kappa \mathrm{B} /$ Rel proteins are bound and inhibited by $\mathrm{I} \kappa \mathrm{B}$ proteins. The PAMPs, DAMPs, pro-inflammatory cytokines, and antigen receptors activate an IKK complex (IKK $\beta$, IKK $\alpha$, and NEMO)

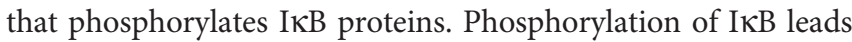
to its ubiquitination and proteasomal degradation, releasing NF$\kappa \mathrm{B} /$ Rel complexes. Active NF- $\kappa \mathrm{B} /$ Rel complexes translocate to the nucleus and induce target gene expression $(84,85)$. Intriguingly, several studies demonstrated that ghrelin inhibits the translocation of LPS-induced NF- $\mathrm{KB}$ (p65) into the nucleus in murine macrophages, which explains the suppressive effects of ghrelin on pro-inflammatory cytokine production by the macrophages after LPS-stimulation $(6,86)$.

The MAPK signaling pathways play an important role in increasing inflammation. Mitogen-activated protein kinase phosphatase-1(MKP-1) provides a negative feedback signal to decrease the activity of MAPKs (87). Studies have shown that the anti-inflammatory effect of ghrelin is due to increased expression of MKP-1, further decreasing the inflammation $(61,88)$.

\section{Ghrelin Increases the Release of Anti-Inflammatory Cytokines}

IL-10 is a cytokine that decreases the production of proinflammatory cytokines including IL- $1 \alpha$ and $-1 \beta$, IL-6, IL-12, 
IL-18, and TNF- $\alpha$ (85). In some studies, it has been found that ghrelin increases the production of IL-10 by enhancing the p38 MAPK (mitogen-activated protein kinase) phosphorylation via the GHSR $(6,27,60)$, which inhibits inflammation by controlling the production of pro-inflammatory cytokines.

\section{ROLE OF GHRELIN IN THE NERVOUS SYSTEM}

The autonomic nervous system plays an important role in inflammation. The activation of the sympathetic nerves stimulates the release of pro-inflammatory cytokines such as TNF- $\alpha(89,90)$. In sepsis, organ failure is promoted by stimulation of the sympathetic nervous system (91-93). Ghrelin protects experimental animals from sepsis-induced organ failure by suppressing the sympathetic nervous system (94-97).

The activation of the parasympathetic nervous system leads to reduced systemic levels of pro-inflammatory cytokines including TNF- $\alpha$ (90). Acetylcholine inhibits the release of IL- $1 \alpha$, IL-1 $\beta$, and IL- 6 cytokines.

Stimulation of vagus nerve attenuates LPS-induced endotoxic shock. It has also been shown that ghrelin can stimulate the vagus nerve $(4,90)$. Ghrelin administration to vagotomized polymicrobial septic mice did not reduce the levels of TNF- $\alpha$, IL-6, AST, ALT, and lactate in contrast to control groups (4). Intact vagus nerve protects the mice from sepsis-induced inflammation and organ injury. This implies that ghrelin mediates its anti-inflammatory properties and protects the experimental animals from organ failure by stimulating the cholinergic anti-inflammatory pathway $(4,98)$.

\section{FUNCTIONS OF GHRELIN ON T CELLS}

During sepsis, although the initial increase in anti-inflammatory cytokines is important, prolonged increases can lead to immunosuppressive conditions resulting in secondary infections. Successful outcomes require a balance between proand anti-inflammatory agents. In sepsis there is a reduction in CD4 T cells, significantly tempering the immune response to infections (99). Treatment with ghrelin rescued the CD4+ population from apoptosis $(5,100)$. Therefore, ghrelin exerts a protective effect by increasing the proliferation of CD4 T cells and decreasing their loss to apoptosis (101).

\section{INTERACTION OF GHRELIN WITH MELANOCORTIN SYSTEM}

One group of investigators have suggested that interaction with elements of the melanocortin system is another possible mechanism by which ghrelin exerts its anti-inflammatory properties. In sepsis and critically ill patients, dysfunction of the hypothalamic-pituitary-adrenal axis occurs leading to corticosteroid insufficiency. Administration of ghrelin stimulates the release of $\mathrm{CRH}, \mathrm{ACTH}$ and corticosterone by acting on HPA axis $(5,32,102)$ (Figure 1). This pathway likely mediates ghrelin effects against inflammation.

\section{INHIBITION OF TH17 CELLS}

Th 17 cells are members of pro-inflammatory T-helper cells and therefore are activated during multiple pro-inflammatory events. Th 17 cells increase the production of IL-17. Mice with knockdown of ghrelin showed significant elevation of IL-17 in T-cells (103). Ghrelin inhibits differentiation of Th17 cells both in vitro and in vivo, thereby exerting anti-inflammatory function. In mice with experimental autoimmune encephalitis, treatment with ghrelin prevented infiltration of Th17 cells and decreased brain damage (104).

\section{AUTOPHAGY}

Autophagy is another important mechanism by which ghrelin can protect organs from injury. Autophagy means eating of self in Greek and plays an important role in clearing damaged organelles such as peroxisomes, endoplasmic reticulum, and mitochondria (105). In many diseases, ghrelin protects neurons, intestinal epithelial cells, vascular smooth muscle cells, heart cells, and hepatocytes from cellular damage by inducing autophagy (106).

\section{ANTIMICROBIAL PROPERTIES OF GHRELIN}

Multiple studies showed the microbicidal actions of ghrelin. Anti-microbial properties of ghrelin-both acylated and desacylated forms of ghrelin possess potent killing properties against microbes, especially gram-negative bacteria. Recall that it is the acylated ghrelin that is the bioactive entity on mammalian entities while the des-acylated versions are not active on mammalian molecular entities.

Des-acyl ghrelin (DAG) was originally thought to be an inert form of acyl ghrelin (AG). However, recent data suggest that DAG can antagonize some aspects of AG function in addition to having GHSR-independent effects.

It is postulated that DAG activates its own receptor and also can interact with AG at this receptor. DAG can be a functional inhibitor of ghrelin and suppress ghrelin levels in humans. Therefore, DAG or DAG analogs can be good candidates for future treatment of metabolic disorders in which antagonism of AG actions could be beneficial like obesity, diabetes, and PraderWilli syndrome (107).

Like many cationic antimicrobial proteins, ghrelin's positive charge was able to counteract the negative charge of bacterial cell 
walls (108). Ghrelin also reduces the bacterial load in the peritoneal fluid of cecal ligation and puncture (CLP)-induced septic mice and demonstrated bactericidal effects on E. coli (109).

\section{ROLE OF GHRELIN IN SEPSIS \\ Effect of Ghrelin on Cell Studies}

In vitro, several studies demonstrated the immunoregulatory role of ghrelin (Figure 3). Treatment with ghrelin inhibited the release of pro-inflammatory cytokines IL- $1 \beta$, IL- 6 , and TNF- $\alpha$ from human monocytes, $\mathrm{T}$ cells, and peripheral blood mononuclear cells (PBMCs) $(55,66)$. Ghrelin also decreased an adipocytokine leptin-induced IL-1 $\beta$, IL-6, and TNF- $\alpha$ protein and gene expression by cultured T cells $(55,127,128)$. Also, ghrelin treatment decreased the TNF- $\alpha$-induced release of IL- 8 and MCP- 1 and the activation of NF- $\kappa \mathrm{B}$ in human umbilical vein endothelial cells (HUVEC) (60). Likewise, ghrelin also decreased the mRNA expression of TNF- $\alpha$ in lymphoid cell lines of children with autism (129). Ghrelin impedes the release of pro-inflammatory cytokines from LPS-stimulated microglial cells (66). It also prevents the release of IL-6 from LPS-stimulated dopaminergic neurons (130). Ghrelin administration reduced LPS-induced expression of proinflammatory cytokines, and inducible NOS in alveolar macrophages. It also reduced LPSinduced NF- $\mathrm{KB}$ translocation in alveolar macrophages (131).

\section{Effect of Ghrelin in Animal Studies}

Several in vivo studies highlighted the anti-inflammatory role of ghrelin in sepsis. In mice with LPS-induced endotoxemia, ghrelin administration produced significant inhibition of release of TNF $\alpha$, IL-6, and IL-1 $\alpha$ (80). In another study in mice, intravenous administration of ghrelin reduced proinflammatory cytokine (TNF $\alpha$, IL-8, and MCP-1) production induced by LPS (60). LPS administration in mice increased levels of TNF $\alpha$ and IL-6; ghrelin reduced the cytokine levels significantly (132). After CLP operation in rats, ghrelin administration led to decreased levels of TNF $\alpha$ and IL-6 (4). Ghrelin decreased both early and late mediators of inflammation. Chorny et al. showed that ghrelin, even 12-24 h after CLP, improved mortality in mice and significantly reduced both clinical parameters and histopathological scores of sepsis, thus proving its effects on late mediators of inflammation (57).

\section{Effect of Ghrelin on Nervous System in Sepsis}

As discussed earlier, the autonomic nervous system plays an important role in inflammation. While the sympathetic nervous system is pro-inflammatory, the parasympathetic nervous system is anti-inflammatory (96). Ghrelin has an inhibitory effect on the sympathetic nervous system and a stimulatory effect on the parasympathetic nervous system. In sepsis, cytokines released by the liver macrophages (also known as Kupffer cells) cross the blood brain barrier and stimulate the hypothalamus and rostral ventrolateral medulla to increase the central sympathetic outflow, causing significant release of catecholamines into the blood which causes further damage to the liver $(96,133)$. These catecholamines act on adrenergic receptors in the liver and stimulate the release of unusually high amounts of TNF- $\alpha$ (134). Ghrelin has been shown to inhibit sympathetic neurons both centrally and peripherally. It has also been shown to stimulate the vagus nerve $(96,133)$. Ghrelin decreased cerebral edema and improved blood brain barrier integrity by decreasing the inflammatory response in the brain of septic mice. It also protected neuronal tissue from oxidative stress and apoptotic damage (135).

\section{Ghrelin Effects on Cognition in Sepsis}

Ghrelin administration in a mouse model induced angiogenesis and neurogenesis in the hippocampus (136). After CLP in rats,

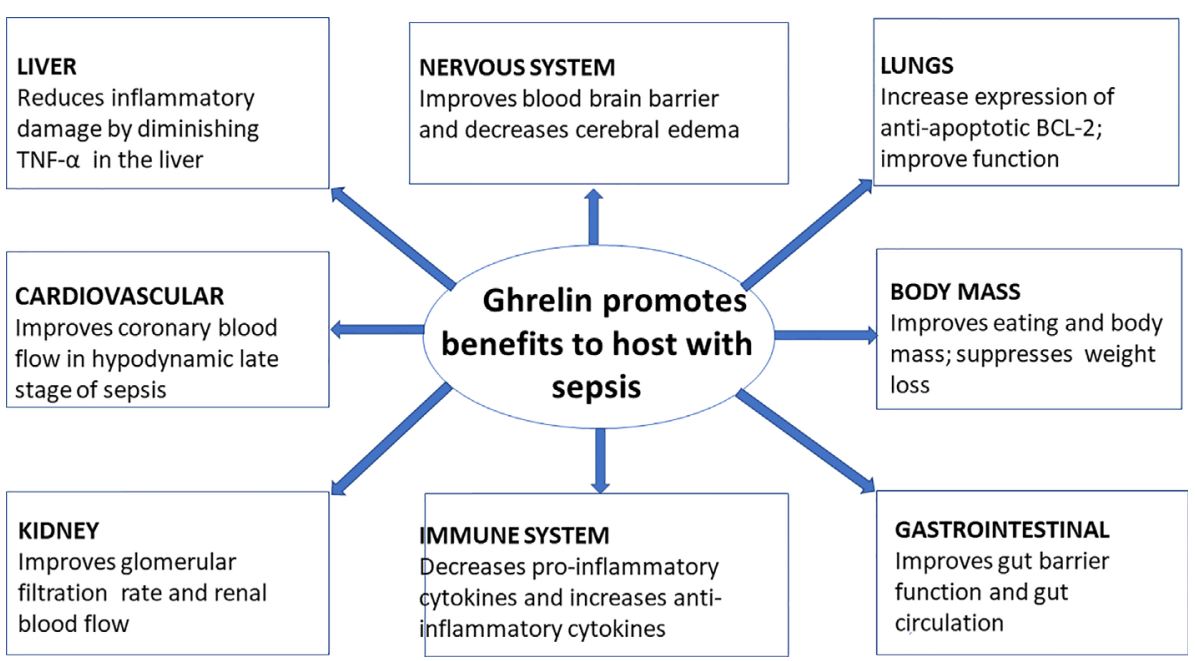

FIGURE 3 | Ghrelin and its effect on various organs during sepsis (110-126). 
ghrelin significantly lowered pro-inflammatory cytokines and inhibited caspase-3 in the hippocampus. It also reduced the density of apoptotic neurons and improved cognition in ghrelintreated rats compared to the control group (137). In addition, ghrelin diminished cognitive impairment associated with septic encephalopathy (138). The expression of ghrelin receptors are reduced with increased age. Therefore, the ghrelin treatment in aged animals is refractory. However, combined treatment with ghrelin and growth hormone overcomes ghrelin unresponsiveness and provides protective role against sepsis. Ghrelin with growth hormone administration after CLP resulted in c-fos expression, a marker of neuronal activation in the brain (139).

\section{Effects of Ghrelin on Respiratory System in Sepsis}

Acute respiratory distress syndrome (ARDS) is another complication associated with sepsis (140). Administration of ghrelin improved pulmonary function and mortality in mice, associated with inhibition of NF- $\mathrm{KB}$ and reduction of proinflammatory cytokines in the lungs (139). In a study done with a synthetic agonist of the ghrelin receptor, LPS-induced lung injury in mice was ameliorated by inhibiting the NF- $\mathrm{BB}$ signaling pathway, which eventually decreased the proinflammatory cytokine production (141). In mouse models, when ARDS was induced with CLP, ghrelin administration inhibited apoptosis of alveolar macrophages (142), protected the integrity of the microvascular barrier and decreased the neutrophil activity in the alveoli (142-144). It has also been found that ghrelin improves outcome in many other lung diseases like pneumonia, pulmonary edema, emphysema, and cystic fibrosis $(110,111)$. Furthermore, treatment with ghrelin showed improvement in lung injury score, by decreasing pulmonary edema, hemorrhage, congestion, and inflammatory cell infiltration in septic mice (132). Ghrelin treatment also reduced the expression of pro-apoptotic BAX and proinflammatory TNF- $\alpha$ but increased the expression of antiapoptotic BCL-2 in LPS-treated mice (112). In this study, tissue superoxide dismutase levels have also been found to be increased with ghrelin administration. In this study, these mechanisms helped to decrease lung injury in mice due to sepsis (112). Another study also reported the beneficial effect of ghrelin on acute lung injury from sepsis by inhibiting NOD2/ NF- $\kappa B$ signaling pathway (86). In this septic mouse model, ghrelin protected the lung tissue from sepsis, by inhibiting neutrophil infiltration and decreasing pro-inflammatory cytokine expression (86). In conclusion, ghrelin improved pulmonary function in mice by decreasing pro-inflammatory cytokines and increasing the expression of anti-apoptotic BCL-2.

\section{Effect of Ghrelin on Cardiovascular System in Sepsis}

In sepsis, another important target is the cardiovascular system. The heart responds to the sepsis by increasing the blood flow initially and then followed by a hypodynamic phase (145). It was suggested by Wang et al. that decreased ghrelin levels in late stages of sepsis might be responsible for low volume states (146). During the hypodynamic phase, endothelin-1 is upregulated which leads to increased vascular resistance leading to decreased organ perfusion (113). Treatment with ghrelin after CLP in mice showed improved cardiac output and stroke volume and thereby improved the organ blood flow in hypodynamic late stage of sepsis. This action of ghrelin is mediated by downregulating endothelin 1 (114). In another study, ghrelin treatment after CLP improved ventricular peak systolic pressure and cardiac contractility by decreasing cytokines like TNF- $\alpha$ and by ghrelin's direct effects on ventricular contraction $(115,116)$.

\section{Effect of Ghrelin on Gastrointestinal System in Sepsis}

While TNF- $\alpha$ and IL- 1 are released early by the macrophages in inflammation, HMGB-1 is a late mediator in sepsis (83). HMGB1 contributes to the increases in gut permeability in sepsis including increase in translocation of bacteria $(147,148)$. In rats, intravenous injection of ghrelin after CLP showed significant reduction in gut permeability and bacterial translocation. This experiment highlighted the important role of ghrelin on gut barrier in sepsis.

Recently, ghrelin has been shown to increase the gastric blood flow, decrease the expression of pro-apoptotic factors like Bax, cleaved caspase-3, and increase the expression of Bcl-2 (149). In a CLP-induced septic mouse model, administration of ghrelin decreased weight loss and intestinal mucosal damage by reducing inflammatory responses. It also improved the function of intestinal epithelial cells of rats (117). In another rat model, treatment with ghrelin after CLP increased the expression of autophagy-associated proteins. This further supports that ghrelin protects intestinal mucosa from sepsis injury (117-121).

\section{Effect of Ghrelin on Liver}

Ghrelin also protects the liver from organ failure (91-93). Treatment of LPS-induced septic mice with growth hormone releasing peptide-2 (GHRP-2), a ghrelin receptor agonist, prevented liver damage. While LPS caused significant elevation of liver enzymes and nitrites/nitrates, ghrelin receptor agonist administration inhibited these increases. In LPS-treated mice, this agonist also increased Insulin-like growth factor-1 (IGF-1) concentration in the serum and expression in hepatocytes (150). IGF-1 plays a significant role in preventing liver damage. Ghrelin receptor agonists also decreased TNF- $\alpha$ expression in the liver, thereby decreasing inflammatory liver damage (122). Ghrelin reduced the hepatic concentration of LPS-induced TNF- $\alpha$, IL$1 \beta$, and IL-6.

\section{Effect of Ghrelin on Musculoskeletal System in Sepsis}

Ghrelin showed significant effects on muscle metabolism. Ghrelin administration to LPS-induced septic rats showed less muscle damage when compared to control groups (123). In another study, prolonged peritonitis was induced with zymosan to measure the influence of ghrelin on muscle metabolism in critical 
illness. This peritonitis caused significant weight loss and reduced food intake in mice. Continuous administration of ghrelin to these mice improved food intake and body mass, but did not increase muscle mass or function (124).

\section{Ghrelin Effects on Kidneys in Sepsis}

TNF- $\alpha$ is a major cytokine involved in the sepsis-related kidney injury $(125,126)$. Ghrelin administration after CLP decreased renal cytokines IL-1 $\beta$, TNF- $\alpha$, IL-6, endothelin, renal inducible nitric oxide synthase (iNOS), and serum NO (nitric oxide). Elevated levels of renal iNOS and NO are responsible for systemic arterial vasodilation which causes renal vasoconstriction leading to acute kidney injury. Ghrelin improved glomerular filtration rate (GFR) and renal blood flow (RBF) in the treatment group when compared to the control group (126). In another study, treatment with ghrelin in CLP-induced septic mice improved inflammatory cytokine levels, kidney function, and arterial blood pressure (151).

\section{Synergistic Effects of Growth Hormone and Ghrelin}

Most experiments done on sepsis studied only a single hormone, but this study combined treatment with two different hormones. Wang et al. showed that combined treatment of ghrelin and growth hormone to aged mice after CLP resulted in improvement in the serum levels of IL- 6 , TNF- $\alpha$, lactate, lactate dehydrogenase, creatinine, and blood urea nitrogen. It also showed decreased apoptosis of CD4 $\mathrm{T}$ cells and expression of inhibitory coreceptors of $\mathrm{T}$ cells $(99,141)$. Growth hormone was added to ghrelin to increase sensitivity of ghrelin receptors (152) in older mice as the expression of ghrelin receptors in aged septic mice is decreased. Addition of growth hormone to ghrelin in septic rats protected lungs, liver, kidneys, heart, and brain from inflammatory damage (141). Combined treatment also provided enhanced immune response from splenocytes to stimulation from LPS and anti-CD3/anti-CD28 antibodies. It also repairs HLA-DR expression, a major histocompatibility complex required by antigen presenting cells in aged septic mice (153). Recent studies demonstrated that growth hormone and ghrelin given together caused inhibition of TGF- $\beta$ via vagus nerve stimulation, thereby maintaining the immune response in septic mice (67).

\section{Ghrelin Improves Radiation-Exposed Septic Mice}

Administration of ghrelin also decreases organ injury and mortality in rats suffering from sepsis after radiation exposure. Exposure to radiation causes gut barrier disruption, which leads to the translocation of intestinal flora to the systemic circulation, leading to inflammation and remote organ injury (154). First, rats were given radiation of 5-Gy followed $48 \mathrm{~h}$ later by polymicrobial sepsis introduced via CLP. Two doses of ghrelin were given immediately after radiation exposure and with CLP. Ghrelin decreased both the attendant weight loss and mortality $(99,154)$.

\section{Ghrelin in Clinical Studies}

Despite the success of ghrelin in improving outcomes for septic rodents, studies in humans are surprisingly sparse. When LPS was administered to healthy volunteers, ghrelin was one of the first hormones to be elevated (155). In neonates with infection (156), ghrelin levels were elevated. Patients with postoperative intra-abdominal sepsis showed a significant increase in ghrelin levels (157). In another study, ghrelin levels were elevated in sepsis patients and levels were inversely related to length of stay in ICU and to SOFA score (134). In another study, lower ghrelin levels were noted in ICU patients, compared to healthy controls $(8,133)$. In patients admitted to ICU for sepsis, ghrelin levels correlated inversely with the length of mechanical ventilation and length of ICU stay (9). In another study, higher serum ghrelin levels in sepsis patients at the time of admission correlated positively with their survival (10). Patients who did not need mechanical ventilation had higher ghrelin levels compared to patients who needed mechanical ventilation. No difference was noted between the concentrations of ghrelin in sepsis versus non-sepsis patients in critically ill ICU patients (10). Overall, in vivo ghrelin levels correlated with better clinical outcomes, but bias favoring positive results has not been excluded.

\section{CONCLUDING REMARKS}

Ghrelin was discovered because of its ability to stimulate growth hormone release. Cells in and around the mucosa of the stomach release ghrelin, a 28-amino acid peptide that promotes growth hormone release from the pituitary and stimulates the appetite.

While most of the ghrelin-producing cells are in the oxyntic mucosa of the stomach, they are found in smaller amounts in and around the fundus of the stomach. Receptors for ghrelin are widely distributed in major organs throughout the body including the CNS and elements of the immune system. The major role of ghrelin may be to act widely to down-regulate inflammatory elements and to promote anti-inflammatory pathways widely throughout the body.

Sepsis occurs from direct microbial infection as well as sterile inflammation caused by ischemia reperfusion injury, postsurgery, and exposure to chemical substances. Moreover, organ transplanted patients are susceptible to infection because of their compromised immune systems. Ghrelin, its agonists, and growth hormone promise to shed light on the therapeutic avenues for the treatment of inflammatory diseases to mitigate organ dysfunction, septic shock, and reduce mortality.

\section{Current Status and Future Direction}

Sepsis, characterized by widespread inflammation with organ dysfunction, continues to be a major cause of illness, disability, and death at all ages. Despite the recruitment of talented professionals and enhanced funding, management of sepsis has advanced slowly. Ghrelin, an anti-inflammatory peptide isolated from cells of the stomach lining, is a major candidate for therapy because of its power to suppress pro-inflammatory processes and enhance anti-inflammatory activities widely throughout the body. In animal studies, ghrelin has beneficial effects widely; effects on the CNS and the immune system are the most 
dramatic. Surprisingly, studies in unison with other candidate therapies and studies in humans are sparse.

\section{AUTHOR CONTRIBUTIONS}

All authors contributed to the article and approved the submitted version.

\section{REFERENCES}

1. Singer M, Deutschman CS, Seymour CW, Shankar-Hari M, Annane D, Bauer M, et al. The Third International Consensus Definitions for Sepsis and Septic Shock (Sepsis-3). JAMA (2016) 315(8):801-10. doi: 10.1001/ jama.2016.0287

2. Sato T, Nakamura Y, Shiimura Y, Ohgusu H, Kangawa K, Kojima M. Structure, regulation and function of ghrelin. J Biochem (2012) 151(2):11928. doi: $10.1093 / \mathrm{jb} / \mathrm{mvr} 134$

3. Kojima M, Hosoda H, Date Y, Nakazato M, Matsuo H, Kangawa K. Ghrelin is a growth-hormone-releasing acylated peptide from stomach. Nature (1999) 402(6762):656-60. doi: 10.1038/45230

4. Wu R, Dong W, Cui X, Zhou M, Simms HH, Ravikumar TS, et al. Ghrelin down-regulates proinflammatory cytokines in sepsis through activation of the vagus nerve. Ann Surg (2007) 245(3):480-6. doi: 10.1097/ 01.sla.0000251614.42290.ed

5. Das UN. Relationship between gut and sepsis: Role of ghrelin. World J Diabetes (2011) 2(1):1-7. doi: 10.4239/wjd.v2.i1.1

6. Waseem T, Duxbury M, Ito H, Ashley SW, Robinson MK. Exogenous ghrelin modulates release of pro-inflammatory and anti-inflammatory cytokines in LPS-stimulated macrophages through distinct signaling pathways. Surgery (2008) 143(3):334-42. doi: 10.1016/j.surg.2007.09.039

7. Date Y, Kojima M, Hosoda H, Sawaguchi A, Mondal MS, Suganuma T, et al. Ghrelin, a novel growth hormone-releasing acylated peptide, is synthesized in a distinct endocrine cell type in the gastrointestinal tracts of rats and humans. Endocrinology (2000) 141(11):4255-61. doi: 10.1210/ endo.141.11.7757

8. Koch A, Sanson E, Helm A, Voigt S, Trautwein C, Tacke F. Regulation and prognostic relevance of serum ghrelin concentrations in critical illness and sepsis. Crit Care (London England) (2010) 14(3):R94. doi: 10.1186/cc9029

9. Wu JT, Kral JG. Ghrelin: integrative neuroendocrine peptide in health and disease. Ann Surg (2004) 239(4):464-74. doi: 10.1097/01.sla.0000118561. 54919.61

10. Seim I, Collet C, Herington AC, Chopin LK. Revised genomic structure of the human ghrelin gene and identification of novel exons, alternative splice variants and natural antisense transcripts. BMC Genomics (2007) 8:298. doi: 10.1186/1471-2164-8-298

11. Dhurandhar EJ, Allison DB, van Groen T, Kadish I. Hunger in the absence of caloric restriction improves cognition and attenuates Alzheimer's disease pathology in a mouse model. PloS One (2013) 8(4):e60437. doi: 10.1371/ journal.pone.0060437

12. Moon M, Choi JG, Nam DW, Hong HS, Choi YJ, Oh MS, et al. Ghrelin ameliorates cognitive dysfunction and neurodegeneration in intrahippocampal amyloid- $\beta 1-42$ oligomer-injected mice. J Alzheimer's Dis $J A D$ (2011) 23(1):147-59. doi: 10.3233/JAD-2010-101263

13. Prodam F, Filigheddu N. Ghrelin gene products in acute and chronic inflammation. Archivum Immunol Ther Experiment (2014) 62(5):369-84. doi: 10.1007/s00005-014-0287-9

14. Liu F, Li Z, He X, Yu H, Feng J. Ghrelin Attenuates Neuroinflammation and Demyelination in Experimental Autoimmune Encephalomyelitis Involving NLRP3 Inflammasome Signaling Pathway and Pyroptosis. Front Pharmacol (2019) 10:1320. doi: 10.3389/fphar.2019.01320

15. Kodama T, Ashitani J, Matsumoto N, Kangawa K, Nakazato M. Ghrelin treatment suppresses neutrophil-dominant inflammation in airways of patients with chronic respiratory infection. Pulmon Pharmacol Ther (2008) 21(5):774-9. doi: 10.1016/j.pupt.2008.05.001

16. Erşahin M, Toklu HZ, Erzik C, Cetinel S, Akakin D, Velioğlu-Oğünç A, et al. The anti-inflammatory and neuroprotective effects of ghrelin in

\section{ACKNOWLEDGMENTS}

The authors would like to thank Dr. Kevin J. Tracey of the Feinstein Institutes for Medical Research for his review of the manuscript. We very much appreciate the generous philanthropic contributions and shared vision of Alan and Tatyana Forman through Altronix Inc.

subarachnoid hemorrhage-induced oxidative brain damage in rats. J Neurotr (2010) 27(6):1143-55. doi: 10.1089/neu.2009.1210

17. Shao XF, Li B, Shen J, Wang QF, Chen SS, Jiang XC, et al. Ghrelin alleviates traumatic brain injury-induced acute lung injury through pyroptosis/NF- $\mathrm{KB}$ pathway. Int Immunopharmacol (2020) 79:106175. doi: 10.1016/ j.intimp.2019.106175

18. Bansal V, Ryu SY, Blow C, Costantini T, Loomis W, Eliceiri B, et al. The hormone ghrelin prevents traumatic brain injury induced intestinal dysfunction. J Neurotr (2010) 27(12):2255-60. doi: 10.1089/neu.2010.1372

19. Cecarini V, Bonfili L, Cuccioloni M, Keller JN, Bruce-Keller AJ, Eleuteri AM. Effects of Ghrelin on the Proteolytic Pathways of Alzheimer's Disease Neuronal Cells. Mol Neurobiol (2016) 53(5):3168-78. doi: 10.1007/s12035015-9227-x

20. Villanueva EC, Münzberg H, Cota D, Leshan RL, Kopp K, Ishida-Takahashi $\mathrm{R}$, et al. Complex regulation of mammalian target of rapamycin complex 1 in the basomedial hypothalamus by leptin and nutritional status. Endocrinology (2009) 150(10):4541-51. doi: 10.1210/en.2009-0642

21. Zhang W, Zhang C, Fritze D, Chai B, Li J, Mulholland MW. Modulation of food intake by mTOR signalling in the dorsal motor nucleus of the vagus in male rats: focus on ghrelin and nesfatin-1. Exp Physiol (2013) 98(12):1696704. doi: 10.1113/expphysiol.2013.074930

22. Vats D, Mukundan L, Odegaard JII, Zhang L, Smith KL, Morel CR, et al. Oxidative metabolism and PGC-1beta attenuate macrophage-mediated inflammation. Cell Metab (2006) 4(1):13-24. doi: 10.1016/ j.cmet.2006.05.011

23. Van den Bossche J, Baardman J, de Winther MP. Metabolic Characterization of Polarized M1 and M2 Bone Marrow-derived Macrophages Using Realtime Extracellular Flux Analysis. J Visualized Experiments JoVE (2015) 105):53424. doi: 10.3791/53424

24. El Eter $\mathrm{E}, \mathrm{Al}$ Tuwaijiri A, Hagar $\mathrm{H}$, Arafa M. In vivo and in vitro antioxidant activity of ghrelin: Attenuation of gastric ischemic injury in the rat. J Gastroenterol Hepatol (2007) 22(11):1791-9. doi: 10.1111/j.14401746.2006.04696.x

25. Konturek PC, Brzozowski T, Pajdo R, Nikiforuk A, Kwiecien S, Harsch I, et al. Ghrelin-a new gastroprotective factor in gastric mucosa. J Physiol Pharmacol An Off J Polish Physiol Soc (2004) 55(2):325-36. doi: 10.1016/ j.regpep.2004.06.016

26. Sibilia V, Rindi G, Pagani F, Rapetti D, Locatelli V, Torsello A, et al. Ghrelin protects against ethanol-induced gastric ulcers in rats: studies on the mechanisms of action. Endocrinology (2003) 144(1):353-9. doi: 10.1210/ en.2002-220756

27. Gonzalez-Rey E, Chorny A, Delgado M. Therapeutic action of ghrelin in a mouse model of colitis. Gastroenterology (2006) 130(6):1707-20. doi: 10.1053/j.gastro.2006.01.041

28. Liu Y, Xu XY, Shen Y, Ye CF, Hu N, Yao Q, et al. Ghrelin protects against obesity-induced myocardial injury by regulating the lncRNA H19/miR-29a/ IGF-1 signalling axis. Exp Mol Pathol (2020) 114:104405. doi: 10.1016/ j.yexmp.2020.104405

29. Kojima M, Kangawa K. Ghrelin: structure and function. Physiol Rev (2005) 85(2):495-522. doi: 10.1152/physrev.00012.2004

30. Delporte C. Structure and physiological actions of ghrelin. Scientifica (2013) 2013:518909. doi: 10.1155/2013/518909

31. Leite-Moreira AF, Soares JB. Physiological, pathological and potential therapeutic roles of ghrelin. Drug Discovery Today (2007) 12(7-8):276-88. doi: 10.1016/j.drudis.2007.02.009

32. Zhou M, Aziz M, Ochani M, Yang WL, Sharma A, Wang P. The protective role of human ghrelin in sepsis: Restoration of $\mathrm{CD} 4 \mathrm{~T}$ cell proliferation. PloS One (2018) 13(7):e0201139. doi: 10.1371/journal.pone.0201139 
33. Zhao TJ, Liang G, Li RL, Xie X, Sleeman MW, Murphy AJ, et al. Ghrelin Oacyltransferase (GOAT) is essential for growth hormone-mediated survival of calorie-restricted mice. Proc Natl Acad Sci U S A (2010) 107(16):7467-72. doi: $10.1073 /$ pnas. 1002271107

34. Zhang Y, Ying B, Shi L, Fan H, Yang D, Xu D, et al. Ghrelin inhibit cell apoptosis in pancreatic beta cell line HIT-T15 via mitogen-activated protein kinase/phosphoinositide 3-kinase pathways. Toxicology (2007) 237(13):194-202. doi: 10.1016/j.tox.2007.05.013

35. Park JM, Kakimoto T, Kuroki T, Shiraishi R, Fujise T, Iwakiri R, et al. Suppression of intestinal mucosal apoptosis by ghrelin in fasting rats. Exp Biol Med (Maywood N J) (2008) 233(1):48-56. doi: 10.3181/0706-RM-169

36. Kim SW, Her SJ, Park SJ, Kim D, Park KS, Lee HK, et al. Ghrelin stimulates proliferation and differentiation and inhibits apoptosis in osteoblastic MC3T3-E1 cells. Bone (2005) 37(3):359-69. doi: 10.1016/j.bone.2005.04.020

37. Dong J, Song N, Xie J, Jiang H. Ghrelin antagonized 1-methyl-4phenylpyridinium $(\mathrm{MPP}(+))$-induced apoptosis in MES23.5 cells. J Mol Neurosci MN (2009) 37(2):182-9. doi: 10.1007/s12031-008-9162-7

38. Kui L, Weiwei Z, Ling L, Daikun H, Guoming Z, Linuo Z, et al. Ghrelin inhibits apoptosis induced by high glucose and sodium palmitate in adult rat cardiomyocytes through the PI3K-Akt signaling pathway. Regul Peptides (2009) 155(1-3):62-9. doi: 10.1016/j.regpep.2009.03.003

39. Zhan M, Yuan F, Liu H, Chen H, Qiu X, Fang W. Inhibition of proliferation and apoptosis of vascular smooth muscle cells by ghrelin. Acta Biochim Biophys Sin (2008) 40(9):769-76. doi: 10.1111/j.1745-7270.2008.00457.x

40. Zhao H, Liu G, Wang Q, Ding L, Cai H, Jiang H, et al. Effect of ghrelin on human endothelial cells apoptosis induced by high glucose. Biochem Biophys Res Commun (2007) 362(3):677-81. doi: 10.1016/j.bbrc.2007.08.021

41. Khatib MN, Gaidhane S, Gaidhane AM, Simkhada P, Zahiruddin QS. Ghrelin O Acyl Transferase (GOAT) as a Novel Metabolic Regulatory Enzyme. J Clin Diagn Res JCDR (2015) 9(2):LE01-LE5. doi: 10.7860/ JCDR/2015/9787.5514

42. Lim CT, Kola B, Grossman A, Korbonits M. The expression of ghrelin Oacyltransferase (GOAT) in human tissues. Endocrine J (2011) 58(8):707-10. doi: 10.1507/endocri.k11e-117

43. Kojima M, Hamamoto A, Sato T. Ghrelin O-acyltransferase (GOAT), a specific enzyme that modifies ghrelin with a medium-chain fatty acid. J Biochem (2016) 160(4):189-94. doi: 10.1093/jb/mvw046

44. Rindi G, Necchi V, Savio A, Torsello A, Zoli M, Locatelli V, et al. Characterisation of gastric ghrelin cells in man and other mammals: studies in adult and fetal tissues. Histochem Cell Biol (2002) 117(6):511-9. doi: 10.1007/s00418-002-0415-1

45. Stengel A, Goebel M, Wang L, Taché Y. Ghrelin, des-acyl ghrelin and nesfatin-1 in gastric X/A-like cells: role as regulators of food intake and body weight. Peptides (2010) 31(2):357-69. doi: 10.1016/j.peptides.2009.11.019

46. Ariyasu H, Takaya K, Tagami T, Ogawa Y, Hosoda K, Akamizu T, et al. Stomach is a major source of circulating ghrelin, and feeding state determines plasma ghrelin-like immunoreactivity levels in humans. J Clin Endocrinol Metab (2001) 86(10):4753-8. doi: 10.1210/jcem.86.10.7885

47. Krsek M, Rosická M, Haluzík M, Svobodová J, Kotrlíková E, Justová V, et al. Plasma ghrelin levels in patients with short bowel syndrome. Endocrine Res (2002) 28(1-2):27-33. doi: 10.1081/erc-120004535

48. Howard AD, Feighner SD, Cully DF, Arena JP, Liberator PA, Rosenblum CII, et al. A receptor in pituitary and hypothalamus that functions in growth hormone release. Sci (N Y N Y ) (1996) 273(5277):974-7. doi: 10.1126/science. 273.5277.974

49. Granado M, Priego T, Martín AII, Villanúa MA, López-Calderón A. Antiinflammatory effect of the ghrelin agonist growth hormone-releasing peptide-2 (GHRP-2) in arthritic rats. Am J Physiol Endocrinol Metab (2005) 288(3):E486-92. doi: 10.1152/ajpendo.00196.2004

50. McKee KK, Palyha OC, Feighner SD, Hreniuk DL, Tan CP, Phillips MS, et al. Molecular analysis of rat pituitary and hypothalamic growth hormone secretagogue receptors. Mol Endocrinol (Baltimore Md) (1997) 11(4):41523. doi: $10.1210 /$ mend.11.4.9908

51. Leung PK, Chow KB, Lau PN, Chu KM, Chan CB, Cheng CH, et al. The truncated ghrelin receptor polypeptide (GHS-R1b) acts as a dominantnegative mutant of the ghrelin receptor. Cell Signal (2007) 19(5):1011-22. doi: 10.1016/j.cellsig.2006.11.011
52. Chow KB, Sun J, Chu KM, Tai Cheung W, Cheng CH, Wise H. The truncated ghrelin receptor polypeptide (GHS-R1b) is localized in the endoplasmic reticulum where it forms heterodimers with ghrelin receptors (GHS-R1a) to attenuate their cell surface expression. Mol Cell Endocrinol (2012) 348(1):247-54. doi: 10.1016/j.mce.2011.08.034

53. Gnanapavan S, Kola B, Bustin SA, Morris DG, McGee P, Fairclough P, et al. The tissue distribution of the mRNA of ghrelin and subtypes of its receptor, GHS-R, in humans. J Clin Endocrinol Metab (2002) 87(6):2988. doi: 10.1210/ jcem.87.6.8739

54. Xia Q, Pang W, Pan H, Zheng Y, Kang JS, Zhu SG. Effects of ghrelin on the proliferation and secretion of splenic T lymphocytes in mice. Regul Peptides (2004) 122(3):173-8. doi: 10.1016/j.regpep.2004.06.016

55. Dixit VD, Schaffer EM, Pyle RS, Collins GD, Sakthivel SK, Palaniappan R, et al. Ghrelin inhibits leptin- and activation-induced proinflammatory cytokine expression by human monocytes and T cells. J Clin Invest (2004) 114(1):57-66. doi: 10.1172/JCI21134

56. Baldanzi G, Filigheddu N, Cutrupi S, Catapano F, Bonissoni S, Fubini A, et al. Ghrelin and des-acyl ghrelin inhibit cell death in cardiomyocytes and endothelial cells through ERK1/2 and PI 3-kinase/AKT. J Cell Biol (2002) 159(6):1029-37. doi: 10.1083/jcb.200207165

57. Chorny A, Anderson P, Gonzalez-Rey E, Delgado M. Ghrelin protects against experimental sepsis by inhibiting high-mobility group box 1 release and by killing bacteria. J Immunol (Baltimore Md 1950) (2008) 180 (12):8369-77. doi: 10.4049/jimmunol.180.12.8369

58. Makki K, Froguel P, Wolowczuk I. Adipose tissue in obesity-related inflammation and insulin resistance: cells, cytokines, and chemokines. ISRN Inflammation (2013) 2013:139239. doi: 10.1155/2013/139239

59. Deshmane SL, Kremlev S, Amini S, Sawaya BE. Monocyte chemoattractant protein-1 (MCP-1): an overview. I Interferon Cytokine Res Off J Int Soc Interferon Cytokine Res (2009) 29(6):313-26. doi: 10.1089/jir.2008.0027

60. Li WG, Gavrila D, Liu X, Wang L, Gunnlaugsson S, Stoll LL, et al. Ghrelin inhibits proinflammatory responses and nuclear factor-kappaB activation in human endothelial cells. Circulation (2004) 109(18):2221-6. doi: 10.1161/ 01.CIR.0000127956.43874.F2

61. Pereira J, da Silva FC, de Moraes-Vieira P. The Impact of Ghrelin in Metabolic Diseases: An Immune Perspective. J Diabetes Res (2017) 2017:4527980. doi: 10.1155/2017/4527980

62. Warzecha Z, Ceranowicz P, Dembinski A, Cieszkowski J, Kusnierz-Cabala B, Tomaszewska R, et al. Therapeutic effect of ghrelin in the course of ceruleininduced acute pancreatitis in rats. J Physiol Pharmacol An Off J Polish Physiol Soc (2010) 61(4):419-27. doi: 10.1371/journal.pone.0121971

63. Deboer MD. Use of ghrelin as a treatment for inflammatory bowel disease: mechanistic considerations. Int J Peptides (2011) 2011:189242. doi: 10.1155/ 2011/189242

64. Sibilia V, Pagani F, Mrak E, Dieci E, Tulipano G, Ferrucci F. Pharmacological characterization of the ghrelin receptor mediating its inhibitory action on inflammatory pain in rats. Amino Acids (2012) 43 (4):1751-9. doi: 10.1007/s00726-012-1260-8

65. Tsuchimochi W, Kyoraku I, Yamaguchi H, Toshinai K, Shiomi K, Kangawa $\mathrm{K}$, et al. Ghrelin prevents the development of experimental diabetic neuropathy in rodents. Eur J Pharmacol (2013) 702(1-3):187-93. doi: 10.1016/j.ejphar.2013.01.035

66. Theil MM, Miyake S, Mizuno M, Tomi C, Croxford JL, Hosoda H, et al. Suppression of experimental autoimmune encephalomyelitis by ghrelin. J Immunol (Baltimore Md 1950) (2009) 183(4):2859-66. doi: 10.4049/ jimmunol.0803362

67. Zhou M, Aziz M, Ochani M, Wang P. Correction of immunosuppression in aged septic rats by human ghrelin and growth hormone through the vagus nerve-dependent inhibition of TGF- $\beta$ production. Mol Med (Cambridge Mass) (2020) 26(1):71. doi: 10.1186/s10020-020-00195-x

68. Zhou X, Xue C. Ghrelin attenuates acute pancreatitis-induced lung injury and inhibits substance P expression. Am J Med Sci (2010) 339(1):49-54. doi: 10.1097/MAJ.0b013e3181b9c3d3

69. Imazu Y, Yanagi S, Miyoshi K, Tsubouchi H, Yamashita S, Matsumoto N, et al. Ghrelin ameliorates bleomycin-induced acute lung injury by protecting alveolar epithelial cells and suppressing lung inflammation. Eur J Pharmacol (2011) 672(1-3):153-8. doi: 10.1016/j.ejphar.2011.09.183 
70. Tian X, Liu Z, Yu T, Yang H, Feng L. Ghrelin ameliorates acute lung injury induced by oleic acid via inhibition of endoplasmic reticulum stress. Life Sci (2018) 196:1-8. doi: 10.1016/j.lfs.2017.07.02

71. Henriques-Coelho T, Correia-Pinto J, Roncon-Albuquerque R. C.OMMAJ.R.X.X.X, Baptista MJ, Lourenço AP, Oliveira SM, et al. Endogenous production of ghrelin and beneficial effects of its exogenous administration in monocrotaline-induced pulmonary hypertension. American journal of physiology. Heart Circulatory Physiol (2004) 287(6): H2885-90. doi: 10.1152/ajpheart.01122.2003

72. Al-Ayed MS, Al-Shaibari KS, Alshehri D, Alzahrani MJ, Nasser I, Alaamri HS, et al. Serum Ghrelin Levels in Saudi Obese Asthmatic School-ChildrenCorrelation with Interleukin-4, Interleukin-5, and Interleukin-21. Int $J$ Environ Res Public Health (2020) 17(5):1656. doi: 10.3390/ijerph17051656

73. Brzozowski T, Konturek PC, Sliwowski Z, Pajdo R, Drozdowicz D, Kwiecien S, et al. Prostaglandin/cyclooxygenase pathway in ghrelin-induced gastroprotection against ischemia-reperfusion injury. J Pharmacol Exp Ther (2006) 319(1):47787. doi: 10.1124/jpet.106.105932

74. Konturek PC, Brzozowski T, Engel M, Burnat G, Gaca P, Kwiecien S, et al. Ghrelin ameliorates colonic inflammation. Role of nitric oxide and sensory nerves. J Physiol Pharmacol An Off J Polish Physiol Soc (2009) 60(2):41-7.

75. Delhanty PJ, Huisman M, Baldeon-Rojas LY, van den Berge I, Grefhorst A, Abribat $T$, et al. Des-acyl ghrelin analogs prevent high-fat-diet-induced dysregulation of glucose homeostasis. FASEB J Off Publ Fed Am Soc Exp Biol (2013) 27(4):1690-700. doi: 10.1096/fj.12-221143

76. Van den Bossche J, Baardman J, Otto NA, van der Velden S, Neele AE, van den Berg SM, et al. Mitochondrial Dysfunction Prevents Repolarization of Inflammatory Macrophages. Cell Rep (2016) 17(3):684-96. doi: 10.1016/ j.celrep.2016.09.008

77. Schmidt FM, Weschenfelder J, Sander C, Minkwitz J, Thormann J, Chittka $\mathrm{T}$, et al. Inflammatory cytokines in general and central obesity and modulating effects of physical activity. PloS One (2015) 10(3):e0121971. doi: 10.1371/journal.pone.0121971

78. Angelino E, Reano S, Ferrara M, Agosti E, Graziani A, Filigheddu N. Antifibrotic activity of acylated and unacylated ghrelin. Int $\mathrm{J}$ Endocrinol (2015) 2015:385682. doi: 10.1155/2015/385682

79. Martín-Romero C, Santos-Alvarez J, Goberna R, Sánchez-Margalet V. Human leptin enhances activation and proliferation of human circulating T lymphocytes. Cell Immunol (2000) 199(1):15-24. doi: 10.1006/ cimm.1999.1594

80. Wang H, Vishnubhakat JM, Bloom O, Zhang M, Ombrellino M, Sama A, et al. Proinflammatory cytokines (tumor necrosis factor and interleukin 1) stimulate release of high mobility group protein-1 by pituicytes. Surgery (1999) 126(2):389-92. doi: 10.1016/S0039-6060(99)70182-0

81. Andersson U, Wang H, Palmblad K, Aveberger AC, Bloom O, ErlandssonHarris $\mathrm{H}$, et al. High mobility group 1 protein (HMG-1) stimulates proinflammatory cytokine synthesis in human monocytes. J Exp Med (2000) 192(4):565-70. doi: 10.1084/jem.192.4.565

82. Sun N, Wang H, Wang L. Protective effects of ghrelin against oxidative stress, inducible nitric oxide synthase and inflammation in a mouse model of myocardial ischemia/reperfusion injury via the HMGB1 and TLR4/NFKB pathway. Mol Med Rep (2016) 14(3):2764-70. doi: 10.3892/mmr. 2016.5535

83. Wang H, Bloom O, Zhang M, Vishnubhakat JM, Ombrellino M, Che J, et al. HMG-1 as a late mediator of endotoxin lethality in mice. Sci (N Y N Y) (1999) 285(5425):248-51. doi: 10.1126/science.285.5425.248

84. Lawrence T. The nuclear factor NF-kappaB pathway in inflammation. Cold Spring Harbor Perspect Biol (2009) 1(6):a001651. doi: 10.1101/ cshperspect.a001651

85. Hayden MS, Ghosh S. Shared principles in NF-kappaB signaling. Cell (2008) 132(3):344-62. doi: 10.1016/j.cell.2008.01.020

86. Peng Z, Zhu Y, Zhang Y, Wilhelmsen K, Jia C, Jin J, et al. Effects of ghrelin on pulmonary NOD2 mRNA expression and NF- $\mathrm{\kappa B}$ activation when protects against acute lung injury in rats challenged with cecal ligation and puncture. Int Immunopharmacol (2012) 13(4):440-5. doi: 10.1016/j.intimp. 2012.04.006

87. Korhonen R, Moilanen E. Mitogen-activated protein kinase phosphatase 1 as an inflammatory factor and drug target. Basic Clin Pharmacol Toxicol (2014) 114(1):24-36. doi: 10.1111/bcpt.12141
88. Jacob A, Rajan D, Pathickal B, Balouch I, Hartman A, Wu R, et al. The inhibitory effect of ghrelin on sepsis-induced inflammation is mediated by the MAPK phosphatase-1. Int J Mol Med (2010) 25(1):159-64. doi: 10.3892/ ijmm_00000326

89. Pongratz G, Straub RH. The sympathetic nervous response in inflammation. Arthritis Res Ther (2014) 16(6):504. doi: 10.1186/s13075-014-0504-2

90. Borovikova LV, Ivanova S, Zhang M, Yang H, Botchkina GII, Watkins LR, et al. Vagus nerve stimulation attenuates the systemic inflammatory response to endotoxin. Nature (2000) 405(6785):458-62. doi: 10.1038/ 35013070

91. Wang P, Chaudry IH. Mechanism of hepatocellular dysfunction during hyperdynamic sepsis. Am J Physiol (1996) 270(5 Pt 2):R927-38. doi: 10.1152/ajpregu.1996.270.5.R927

92. Koo DJ, Chaudry IH, Wang P. Kupffer cells are responsible for producing inflammatory cytokines and hepatocellular dysfunction during early sepsis. J Surg Res (1999) 83(2):151-7. doi: 10.1006/jsre.1999.5584

93. Aninat C, Seguin P, Descheemaeker PN, Morel F, Malledant Y, Guillouzo A. Catecholamines induce an inflammatory response in human hepatocytes. Crit Care Med (2008) 36(3):848-54. doi: 10.1097/CCM.0B013E31816532BE

94. Wu R, Dong W, Zhou M, Zhang F, Marini CP, Ravikumar TS, et al. Ghrelin attenuates sepsis-induced acute lung injury and mortality in rats. Am J Respiratory Crit Care Med (2007) 176(8):805-13. doi: 10.1164/rccm.200604$5110 \mathrm{C}$

95. Wu R, Dong W, Qiang X, Wang H, Blau SA, Ravikumar TS, et al. Orexigenic hormone ghrelin ameliorates gut barrier dysfunction in sepsis in rats. Crit Care Med (2009) 37(8):2421-6. doi: 10.1097/CCM.0b013e3181a557a2

96. Cheyuo C, Jacob A, Wang P. Ghrelin-mediated sympathoinhibition and suppression of inflammation in sepsis. Am J Physiol Endocrinol Metab (2012) 302(3):E265-72. doi: 10.1152/ajpendo.00508.2011

97. Wu R, Zhou M, Das P, Dong W, Ji Y, Yang D, et al. Ghrelin inhibits sympathetic nervous activity in sepsis. Am J Physiol Endocrinol Metab (2007) 293(6):E1697-702. doi: 10.1152/ajpendo.00098.2007

98. Jacob A, Wu R, Zhou M, Coppa GF, Wang P. Mechanism of the inhibitory effect of ghrelin in sepsis. Hepatic Med Evid Res (2010) 2:33-8. doi: 10.2147/ hmer.s7187

99. Aziz M, Yang WL, Matsuo S, Sharma A, Zhou M, Wang P. Upregulation of GRAIL is associated with impaired CD4 $\mathrm{T}$ cell proliferation in sepsis. J Immunol (Baltimore Md 1950) (2014) 192(5):2305-14. doi: 10.4049/ jimmunol.1302160

100. Cabrera-Perez J, Condotta SA, Badovinac VP, Griffith TS. Impact of sepsis on CD4 T cell immunity. J Leukocyte Biol (2014) 96(5):767-77. doi: 10.1189/ jlb.5MR0114-067R

101. Lee JH, Patel K, Tae HJ, Lustig A, Kim JW, Mattson MP, et al. Ghrelin augments murine $\mathrm{T}$-cell proliferation by activation of the phosphatidylinositol-3-kinase, extracellular signal-regulated kinase and protein kinase C signaling pathways. FEBS Lett (2014) 588(24):4708-19. doi: 10.1016/j.febslet.2014.10.044

102. Wren AM, Small CJ, Fribbens CV, Neary NM, Ward HL, Seal LJ, et al. The hypothalamic mechanisms of the hypophysiotropic action of ghrelin. Neuroendocrinology (2002) 76(5):316-24. doi: 10.1159/000066629

103. Dixit VD, Yang H, Cooper-Jenkins A, Giri BB, Patel K, Taub DD. Reduction of $\mathrm{T}$ cell-derived ghrelin enhances proinflammatory cytokine expression: implications for age-associated increases in inflammation. Blood (2009) 113 (21):5202-5. doi: 10.1182/blood-2008-09-181255

104. Xu Y, Li Z, Yin Y, Lan H, Wang J, Zhao J, et al. Ghrelin inhibits the differentiation of Thelper 17 cells through mTOR/STAT3 signaling pathway. PloS One (2015) 10(2):e0117081. doi: 10.1371/journal.pone.0117081

105. Glick D, Barth S, Macleod KF. Autophagy: cellular and molecular mechanisms. J Pathol (2010) 221(1):3-12. doi: 10.1002/path.2697

106. Yanagi S, Sato T, Kangawa K, Nakazato M. The Homeostatic Force of Ghrelin. Cell Metab (2018) 27(4):786-804. doi: 10.1016/j.cmet.2018.02.008

107. Delhanty PJ, Neggers SJ, van der Lely AJ. Mechanisms in endocrinology: Ghrelin: the differences between acyl- and des-acyl ghrelin. Eur J Endocrinol (2012) 167(5):601-8. doi: 10.1530/EJE-12-0456

108. . doi: 10.1530/EJE-12-0456

109. Min C, Ohta K, Kajiya M, Zhu T, Sharma K, Shin J, et al. The antimicrobial activity of the appetite peptide hormone ghrelin. Peptides (2012) 36(2):1516. doi: $10.1016 /$ j.peptides.2012.05.006 
110. Bernard GR, Artigas A, Brigham KL, Carlet J, Falke K, Hudson L, et al. The American-European Consensus Conference on ARDS. Definitions, mechanisms, relevant outcomes, and clinical trial coordination. Am J Respiratory Crit Care Med (1994) 149(3 Pt 1):818-24. doi: 10.1164/ ajrccm.149.3.7509706

111. Chen J, Liu X, Shu Q, Li S, Luo F. Ghrelin attenuates lipopolysaccharideinduced acute lung injury through NO pathway. Med Sci Monitor Int Med J Exp Clin Res (2008) 14(7):BR141-6. doi: 10.1089/ars.2007.1785

112. Schwenke DO, Tokudome T, Shirai M, Hosoda H, Horio T, Kishimoto I, et al. Exogenous ghrelin attenuates the progression of chronic hypoxiainduced pulmonary hypertension in conscious rats. Endocrinology (2008) 149(1):237-44. doi: 10.1210/en.2007-0833

113. Wu R, Zhou M, Cui X, Simms HH, Wang P. Upregulation of cardiovascular ghrelin receptor occurs in the hyperdynamic phase of sepsis. Am J Physiol Heart Circulatory Physiol (2004) 287(3):H1296-302. doi: 10.1152/ ajpheart.00852.2003

114. Szalay L, Kaszaki J, Nagy S, Boros M. The role of endothelin-1 in circulatory changes during hypodynamic sepsis in the rat. Shock (Augusta Ga) (1998) 10 (2):123-8. doi: 10.1097/00024382-199808000-00007

115. Wu R, Dong W, Zhou M, Cui X, Hank Simms H, Wang P. Ghrelin improves tissue perfusion in severe sepsis via downregulation of endothelin-1. Cardiovasc Res (2005) 68(2):318-26. doi: 10.1016/i.cardiores.2005.06.011

116. Chang L, Ren Y, Liu X, Li WG, Yang J, Geng B, et al. Protective effects of ghrelin on ischemia/reperfusion injury in the isolated rat heart. J Cardiovasc Pharmacol (2004) 43(2):165-70. doi: 10.1097/00005344-200402000-00001

117. Li B, Lin Q, Guo H, Liu L, Li Y. Ghrelin regulates sepsis-induced rat acute gastric injury. Mol Med Rep (2019) 19(6):5424-32. doi: 10.3892/ mmr.2019.10208

118. Wan SX, Shi B, Lou XL, Liu JQ, Ma GG, Liang DY, et al. Ghrelin protects small intestinal epithelium against sepsis-induced injury by enhancing the autophagy of intestinal epithelial cells. Biomed Pharmacother Biomed Pharmacother (2016) 83:1315-20. doi: 10.1016/j.biopha.2016.08.048

119. Suzuki H, Matsuzaki J, Hibi T. Ghrelin and oxidative stress in gastrointestinal tract. J Clin Biochem Nutr (2011) 48(2):122-5. doi: 10.3164/jcbn.10-16GFR

120. Faim F, Passaglia P, Batalhao M, Lacchini R, Stabile AM, Carnio EC. Role of ghrelin on growth hormone/insulin-like growth factor-1 axis during endotoxemia. Growth Hormone IGF Res Off J Growth Hormone Res Soc Int IGF Res Soc (2019) 48-49:36-44. doi: 10.1016/j.ghir.2019.08.004

121. Granado M, Martín AII, López-Menduiña M, López-Calderón A, Villanúa MA. GH-releasing peptide-2 administration prevents liver inflammatory response in endotoxemia. Am J Physiol Endocrinol Metab (2008) 294(1): E131-41. doi: 10.1152/ajpendo.00308.2007

122. Hill NE, Murphy KG, Saeed S, Phadke R, Chambers D, Wilson DR, et al. Impact of ghrelin on body composition and muscle function in a long-term rodent model of critical illness. PloS One (2017) 12(8):e0182659. doi: 10.1371/journal.pone. 0182659

123. Schrier RW, Wang W. Acute renal failure and sepsis. New Engl J Med (2004) 351(2):159-69. doi: 10.1056/NEJMra032401

124. Wang W, Bansal S, Falk S, Ljubanovic D, Schrier R. Ghrelin protects mice against endotoxemia-induced acute kidney injury. Am J Physiol Renal Physiol (2009) 297(4):F1032-7. doi: 10.1152/ajprenal.00044.2009

125. Khowailed A, Younan SM, Ashour H, Kamel AE, Sharawy N. Effects of ghrelin on sepsis-induced acute kidney injury: one step forward. Clin Exp Nephrol (2015) 19(3):419-26. doi: 10.1007/s10157-014-1006-x

126. Wu R, Zhou M, Dong W, Ji Y, Miksa M, Marini CP, et al. Ghrelin hyporesponsiveness contributes to age-related hyperinflammation in septic shock. Ann Surg (2009) 250(1):126-33. doi: 10.1097/SLA.0b013 e3181ad85d6

127. Narula T, deBoisblanc BP. Ghrelin in Critical Illness. Am J Respiratory Cell Mol Biol (2015) 53(4):437-42. doi: 10.1165/rcmb.2014-0226TR

128. Loffreda S, Yang SQ, Lin HZ, Karp CL, Brengman ML, Wang DJ, et al. Leptin regulates proinflammatory immune responses. FASEB J Off Publ Fed Am Soc Exp Biol (1998) 12(1):57-65. doi: 10.1096/fsb2fasebj.12.1.57

129. La Cava A. Leptin in inflammation and autoimmunity. Cytokine (2017) 98:51-8. doi: 10.1016/j.cyto.2016.10.011

130. Yamashita Y, Makinodan M, Toritsuka M, Yamauchi T, Ikawa D, Kimoto S, et al. Anti-inflammatory Effect of Ghrelin in Lymphoblastoid Cell Lines
From Children With Autism Spectrum Disorder. Front Psychiatry (2019) 10:152. doi: 10.3389/fpsyt.2019.00152

131. Beynon AL, Brown MR, Wright R, Rees MII, Sheldon IM, Davies JS. Ghrelin inhibits LPS-induced release of IL-6 from mouse dopaminergic neurones. J Neuroinflam (2013) 10:40. doi: 10.1186/1742-2094-10-40

132. Zheng $\mathrm{H}$, Liang $\mathrm{W}, \mathrm{He} \mathrm{W}$, Huang $\mathrm{C}$, Chen Q, Yi H, et al. Ghrelin attenuates sepsis-induced acute lung injury by inhibiting the NF- $\kappa B$, iNOS, and Akt signaling in alveolar macrophages. Am J Physiol Lung Cell Mol Physiol (2019) 317(3):L381-91. doi: 10.1152/ajplung.00253.2018

133. Nikitopoulou I, Kampisiouli E, Jahaj E, Vassiliou AG, Dimopoulou I, Mastora Z, et al. Ghrelin alterations during experimental and human sepsis. Cytokine (2020) 127:154937. doi: 10.1016/j.cyto.2019.154937

134. Aziz M, Jacob A, Yang WL, Matsuda A, Wang P. Current trends in inflammatory and immunomodulatory mediators in sepsis. J Leukocyte Biol (2013) 93(3):329-42. doi: 10.1189/jlb.0912437

135. Miksa M, Das P, Zhou M, Wu R, Dong W, Ji Y, et al. Pivotal role of the alpha (2A)-adrenoceptor in producing inflammation and organ injury in a rat model of sepsis. PloS One (2009) 4(5):e5504. doi: 10.1371/ journal.pone.0005504

136. Sun N, Wang H, Ma L, Lei P, Zhang Q. Ghrelin attenuates brain injury in septic mice via PI3K/Akt signaling activation. Brain Res Bull (2016) 124:27885. doi: 10.1016/j.brainresbull.2016.06.002

137. Chen R. Ghrelin improves cognitive function in mice by increasing the production of insulin-like growth factor-I in the hippocampus. Nagoya Med J (2012) 52:117-34. doi: 10.1097/SLA.0b013e3181ad85d6

138. Wei H, Cao X, Zeng Q, Zhang F, Xue Q, Luo Y, et al. Ghrelin inhibits proinflammatory responses and prevents cognitive impairment in septic rats. Crit Care Med (2015) 43(5):e143-50. doi: 10.1097/CCM.00000 00000000930

139. Wang G, Wang W, Zhao J, Ni Y, Zhou X, Zhang W. Ghrelin prevents neuronal apoptosis and cognitive impairments in sepsis-associated encephalopathy. Neuroreport (2011) 22(18):959-64. doi: 10.1097/ WNR.0b013e32834d38ce

140. Yang WL, Ma G, Zhou M, Aziz M, Yen HT, Marvropoulos SA, et al. Combined Administration of Human Ghrelin and Human Growth Hormone Attenuates Organ Injury and Improves Survival in Aged Septic Rats. Mol Med (Cambridge Mass) (2016) 22:124-35. doi: 10.2119/ molmed.2015.00255

141. Guo RF, Ward PA. Role of oxidants in lung injury during sepsis. Antioxid Redox Signaling (2007) 9(11):1991-2002. doi: 10.1089/ars.2007.1785

142. Li G, Li J, Zhou Q, Song X, Liang H, Huang L. Growth hormone releasing peptide-2, a ghrelin agonist, attenuates lipopolysaccharide-induced acute lung injury in rats. Tohoku J Exp Med (2010) 222(1):7-13. doi: 10.1620/ tjem.222.7

143. Li B, Zeng M, He W, Huang X, Luo L, Zhang H, et al. Ghrelin protects alveolar macrophages against lipopolysaccharide-induced apoptosis through growth hormone secretagogue receptor 1a-dependent c-Jun $\mathrm{N}$-terminal kinase and $\mathrm{Wnt} / \beta$-catenin signaling and suppresses lung inflammation. Endocrinology (2015) 156(1):203-17. doi: 10.1210/ en.2014-1539

144. Matthay MA, Zimmerman GA. Acute lung injury and the acute respiratory distress syndrome: four decades of inquiry into pathogenesis and rational management. Am J Respiratory Cell Mol Biol (2005) 33(4):319-27. doi: $10.1165 /$ rcmb.F305

145. Yorulmaz H, Ozkok E, Ates G, Tamer S. Investigation of the effectiveness of ghrelin treatment in lung tissue of rats with sepsis. Bratislavske Lekarske Listy (2017) 118(10):585-90. doi: 10.4149/BLL_2017_112

146. Yang S, Chung CS, Ayala A, Chaudry IH, Wang P. Differential alterations in cardiovascular responses during the progression of polymicrobial sepsis in the mouse. Shock (Augusta Ga) (2002) 17(1):55-60. doi: 10.1097/00024382200201000-00010

147. Wu R, Chaung WW, Dong W, Ji Y, Barrera R, Nicastro J, et al. Ghrelin maintains the cardiovascular stability in severe sepsis. J Surg Res (2012) 178 (1):370-7. doi: 10.1016/j.jss.2011.12.021

148. Sappington PL, Yang R, Yang H, Tracey KJ, Delude RL, Fink MP. HMGB1 B box increases the permeability of Caco-2 enterocytic monolayers and impairs intestinal barrier function in mice. Gastroenterology (2002) 123(3):790-802. doi: 10.1053/gast.2002.35391 
149. Yang R, Harada T, Mollen KP, Prince JM, Levy RM, Englert JA, et al. AntiHMGB1 neutralizing antibody ameliorates gut barrier dysfunction and improves survival after hemorrhagic shock. Mol Med (Cambridge Mass) (2006) 12(4-6):105-14. doi: 10.2119/2006-00010.Yang

150. Yorulmaz H, Ozkok E, Ates G, Aksu A, Balkis N, Ghrelin TS. Impact on Muscle Energy Metabolism in Sepsis. Int J Pept Res Ther (2018) 24:259-64. doi: 10.1007/s10989-017-9610-8

151. Zhou M, Yang WL, Aziz M, Ma G, Wang P. Therapeutic effect of human ghrelin and growth hormone: Attenuation of immunosuppression in septic aged rats. Biochim Biophys Acta Mol Basis Dis (2017) 1863(10 Pt B):2584-93. doi: 10.1016/j.bbadis.2017.01.014

152. Shah KG, Wu R, Jacob A, Blau SA, Ji Y, Dong W, et al. Human ghrelin ameliorates organ injury and improves survival after radiation injury combined with severe sepsis. Mol Med (Cambridge Mass) (2009) 15(1112):407-14. doi: 10.2119/molmed.2009.00100

153. Vila G, Maier C, Riedl M, Nowotny P, Ludvik B, Luger A, et al. Bacterial endotoxin induces biphasic changes in plasma ghrelin in healthy humans. J Clin Endocrinol Metab (2007) 92(10):3930-4. doi: 10.1210/jc.2007-1194

154. Siahanidou T, Margeli A, Tsirogianni C, Hantzi E, Papassotiriou I, Chrousos G. Elevated circulating ghrelin, but not peptide YY(3-36) levels, in term neonates with infection. Clin Chem Lab Med (2015) 53(11):1815-24. doi: 10.1515/cclm2014-1250
155. Maruna P, Gürlich R, Frasko R, Rosicka M. Ghrelin and leptin elevation in postoperative intra-abdominal sepsis. Eur Surg Res Europaische Chirurgische Forschung Recherches Chirurgicales Europeennes (2005) 37(6):354-9. doi: 10.1159/000090336

156. Nematy M, O’Flynn JE, Wandrag L, Brynes AE, Brett SJ, Patterson M, et al. Changes in appetite related gut hormones in intensive care unit patients: a pilot cohort study. Crit Care (London England) (2006) 10(1):R10. doi: 10.1186/cc3957

157. Arabi YM, Jawdat D, Al-Dorzi HM, Tamim H, Tamimi W, Bouchama A, et al. Leptin, Ghrelin, and Leptin/Ghrelin Ratio in Critically Ill Patients. Nutrients (2019) 12(1):36. doi: 10.3390/nu12010036

Conflict of Interest: The authors declare that the research was conducted in the absence of any commercial or financial relationships that could be construed as a potential conflict of interest.

Copyright (C) 2021 Mathur, Mehdi, Anipindi, Aziz, Khan, Kondakindi, Lowell, Wang and Roth. This is an open-access article distributed under the terms of the Creative Commons Attribution License (CC BY). The use, distribution or reproduction in other forums is permitted, provided the original author(s) and the copyright owner(s) are credited and that the original publication in this journal is cited, in accordance with accepted academic practice. No use, distribution or reproduction is permitted which does not comply with these terms. 